\title{
International Registrations of Cultivar Names for Unassigned Woody Genera
}

\author{
Donald G. Huttleston ${ }^{1}$ \\ Longwood Gardens, P.O. Box 501, Kennett Square, PA 19348-0501, USA
}

\begin{abstract}
During 1989, 13 cultivar names in unassigned woody genera were registered. Anyone who is involved in the origination or introduction of new cultivars of ornamental plants is urged to see that the names are registered with a view toward nomenclatural stabilization. A list of International Registration Authorities for cultivar names is published in this issue of HortScience, and subsequent updates will be available from the American Association of Botanical Gardens and Arboreta (AABGA), 786 Church Road, Wayne, PA 19087, USA.
\end{abstract}

Artemisia stelleriana Besser 'Silver Brocade'. Registered 27 Jan. 1989. Registrant: Gerald B. Straley, Univ. of British Columbia, 6501 N.W. Marine Drive, Vancouver, BC V6T IW5, Canada. The original plant of this Botanical Garden selection was a chance seedling in Great Windsor Park, England, and was selected' before 1983 because of its spreading habit and silver-gray foliage, and its lack of unattractive flowers during its first year or two from cuttings. It forms a plant $40 \mathrm{~cm}$ tall that spreads more than $1 \mathrm{~m}$ in 3 years. It is an excellent contrast with brightly colored flowers. It cascades when in containers, is easily propagated from cuttings, and is a vigorous. grower. It differs from other forms in its broader, larger leaves. It is very hardy and does best in well-drained soil and full sun. It was commercially introduced by the Univ. of British Columbia in 1989.

Fothergilla gardenii J.Murr. 'Blue Mist'. Registered 27 Jan. 1989. Registrant: Rick J. Lewandowski, Morris Arboretum of the Univ. of Pennsylvania, 9414 Meadowbrook Ave., Philadelphia, Pennsylvania 19118, USA. The parent of this selection was an old plant in the Morris Arboretum, the source of which was unknown. It was selected in 1979 by the Arboretum staff because of its distinctive glaucous, blue-green foliage, which is dramatically different from other plants of the species. It does well in acid soils in sun or partial shade and is hardy in USDA Zones 5-9. It was described and discussed in American Nurseryman 166(11):70-94. 1987 and in The Public Garden 4(4):36. 1989.

Hibiscus syriacus L. 'Edna Frances', Baker 1986. Registered 7 Nov. 1989. Registrant R.P. Baker, 8 Grove Footpath, Surbiton, Surrey KT5 8AT, England, UK. The original plant of this selection was cultivated in Mr. Baker's garden in 1986 and chosen because of its single-stemmed, compact habit and its abundant 6- to 7-cm red-purple (RHS 73A) flowers, with crimson throats. It becomes a 2-m-tall shrub with a 1-m spread in 8 years and is hardy to USDA Zone 5 .

Lonicera sempervirens L . 'Major Wheeler', Wheeler 1980. Registered 7 Aug. 1989. Registrant: J.R. Massey, Dept. of Biology, Univ. of North Carolina, Chapel Hill, North Carolina 27514, USA. The original plant of this selection was a wild plant in Salter Path. North Carolina, chosen by Charles Wheeler, General Administration, Univ. of North Carolina, Chapel Hill, North Carolina 27514, in 1980 because of its ever-blooming performance. Its leaves, green above, are glaucous beneath and lanceolate to broadly ovate. The uppermost

'Horticultural Taxonomist, retired, Longwood Gardens. pair of leaves are connate perfoliate. The flowers are home mostly in fours in axillary or terminal glomerules. The slightly zygomorphic corollas are scarlet to crimson.

Potentilla fruticosa L. 'Yellow Gem', Putnam 1965. Registered 17 Jan. 1989. Registrant: Gerald B. Straley, Univ. of British Columbia Botanical Garden, 6501 N.W. Marine Drive, Vancouver, BC V6T 1W5, Canada. The original plant of this cultivar was a wild plant in the Univ. of British Columbia Botanical Garden selected by Robert Putnam, Kirkland Washington. It forms a low, compact mound, $40 \mathrm{~cm}$ high with a more than 1-m spread, with gray-green leaves and large $(3-\mathrm{cm})$ bright yellow (RHS Yellow Group 9) flowers with ruffle-edged petals. It is hardy in USDA Zones 2-9 and does well in average, welldrained soils in sun. It was commercially introduced in 1989 by the Univ. of British Columbia.

Prunus tenella Batsch. 'Ruth's 100', Weinstein 1982, Registered 17 Nov. 1989. Registrant Gayle Weinstein, Denver Botanic Gardens, 909 York Street, Denver, Colorado 80206-3799, USA. Ms. Weinstein selected a seedling in the USDA Cheyenne Horticultural Field Station in 1987 because of its compact habit, its drought tolerance, and its abundant flowers in April. It forms a $90-\mathrm{cm}$ shrub with a $90-\mathrm{cm}$ spread in 7 years, adding 10 to $15 \mathrm{~cm}$ a year. It is very adaptable and hardy to USDA Zone 2.

Sorbus rufoferruginea (Schneid.) Schneid. 'Longwood Sunset', Thomas 1988. Registered 5 Sept. 1989. Registrant: Bill Thomas, Longwood Gardens, Box 501, Kennett Square, Pennsylvania 19348-0501, USA. In 1988, Mr. Thomas selected a tree in Longwood Gardens' arboretum because of its rich burgundy fall foliage, retained for 3 weeks in October, and its orange fruits, which are showy through December. The 25year-old tree is $6 \mathrm{~m}$ tall and $6 \mathrm{~m}$ in diameter. It does well in heavy clay soil and will likely tolerate any well-drained soil. It is hardy is USDA Zones 4-7.

The following six lowbush blueberries were registered by Ann Crichton-Harris, Pleasant River Landscape, Columbia Falls, Maine 04623, USA. They were selected for their ornamental rather than fruit value from formerly wild plants at the Maine Agricultural Experimental Farm, Jonesboro. All are low (13 to $18 \mathrm{~cm}$ ), spreading ground covers that are hardy in USDA Zones 2-7.

Vaccinium angustifolium Ait. 'Burgundy', Crichton-Harris 1987, Registered 27 Nov. 1989. 'Burgundy', as the name implies, was selected in Sept. 1987 because of its deep burgundy (Munsell page $5 \mathrm{R}$ 4/4) fall foliage, which it retains until mid-October.

Vaccinium angustifolium Ait, 'Claret', CrichtonHarris 1987. Registered 27 Nov. 1989. This clone was selected because of its deep red (Munsell page $10 \mathrm{R}$ 4/6) fall foliage, which it retains to early October, and its red stems, which are attractive in winter.

Vaccinium angustifolium Ait. 'Jonesboro', Crichton-Harris 1987. Registered 27 Nov. 1989. This plant was selected because of its deep red stems and its pinkish red (Munsell page $5 \mathrm{R}$ 4/8) fall color until early October. 
Vaccinium angustifolium Ait. 'Pretty Yellow', Crichton-Harris 1988. Registered 27 Nov. 1989. The unusual greenish-yellow (Munsell page 5 Y 7/8) fall coloration makes this clone startling among the usual red clones.

Vaccinium angustifolium Ait. 'Spring', CrichtonHarris 1987. Registered 27 Nov. 1989. The lush green fall foliage of this clone makes it a striking contrast with the usual reds of other plants.

Vaccinium angustifolium Ait. 'Verde', CrichtonHarris 1987. Registered 27 Nov. 1989. The bright green stems give these plants an iridescent glow, particularly in sunlight. The foliage also remains green, and the fruit yield is large,

\title{
Cultivar Registration at the Arnold Arboretum 1989
}

\author{
Stephen A. Spongberg \\ The Arnold Arboretum, 125 The Arborway, Jamaica Plain, MA 02130, USA
}

The Arnold Arboretum of Harvard University continues to serve as International Registration Authority for cultivar names in 11 genera of ornamental woody plants, and the following notes pertain to cultivar names that have been registered at the Arboretum during 1987 and 1988. The 11 genera include: Chaenomeles, Cornus, Fagus, Forsythia, Gleditsia, Lantana, Malus (ornamental species), Philadelphus, Pieris, Ulmus, and Weigela. Inquiries concerning the registration of cultivar names in these genera should be addressed to Dr. S.A. Spongberg, The Arnold Arboretum, The Arborway, Jamaica Plain, MA 02130, USA.

Cultivar names registered during 1988 include the following in Cornus and Pieris.

Cornus florida L. 'Cherokee Maiden'. Registered 21 Feb. 1989. Registrant: John C. Pair, Research Horticulturist, Horticultural Research Center, Kansas State Univ., 1901 East, 95th Street South, Wichita, Kansas 67233, USA. The seed from which 'Cherokee Maiden' was grown was collected in the Cook- son Hills region of Oklahoma by Ben Davis II, of the former Ozark Nurseries of Tahlequak, Oklahoma. The plant has been named and is being introduced by John C. Pair of the Kansas State Univ. Horticulture Research Center because of its superior winter hardiness. It was selected for hardiness from among 125 plants when it flowered after sustaining $-30.5 \mathrm{C}$ temperatures during Winter 1982. In freezing tests conducted by Dr. Howard Pellett at the Univ. of Minnesota, the flower buds have survived temperatures between -30 to $-31 \mathrm{C}$.

Pieris 'Clifford Stevens'. Registered 9 Mar. 1989. Registrant: C.R.G. Stevens, Woodgate, South Munstead Lane, Godalming, Surrey GU8 4AG, England. 'Clifford Stevens' is a sport of Pieris 'Forest Flame', with leaves variegated creamy white. Similar to 'Forest Flame', the new growth carries shades of bright red to greenish pink, and 'Clifford Stevens' tolerates the same conditions of cultivation and hardiness. 'Clifford Stevens' is currently on trial at the Royal Horticultural Society's Garden at Wisley.

${ }^{1}$ Horticultural Taxonomist, The Arnold Arboretum. 